\title{
Evaluation of the Healing Potential of Myracrodruon urundeuva in Wounds Induced in Male Rats
}

\author{
Monalisa C. Teixeira ${ }^{1}$. Maria Janice P. Lopes ${ }^{1}$ - Dárcio Luiz de Sousa-Júnior ${ }^{1}$ • Ana E. S. Ribeiro ${ }^{1} \cdot$ Bruna S. Pereira $^{1}$. \\ Pedro Everson A. de Aquino ${ }^{2}$ - Nayara C. de Aquino ${ }^{2}$ - Edilberto R. Silveira ${ }^{2}$ - Luzia Kaline A. M. Leal ${ }^{3}$. \\ Glauce Socorro de B. Viana ${ }^{3}$
}

Received: 20 July 2019 / Accepted: 9 December 2019 / Published online: 9 March 2020

(C) The Author(s) 2020

\begin{abstract}
Myracrodruon urundeuva Allemão, Anacardiaceae, is popularly known as "aroeira-do-sertão". It is a common species in the state of Ceará and widely used for its anti-inflammatory, anti-ulcer, astringent, anti-allergic, and antidiarrheal activities and also in the treatment of skin wounds. The aim of this study was to evaluate the healing effect of the cream prepared with the decoction from the stem bark of a 7-year-old cultivated M. urundeuva in rats submitted to excisional wounds. Male Wistar rats were divided into three groups: sham group, which did not received a treatment; $10 \%$ "aroeira" cream group, which received application of the plant cream; and control group, which received application of the base cream. The animals had their skin fragments ( $8 \mathrm{~mm}$ in diameter) removed, and each group was observed at 2, 7, and 12 days after surgery. The macroscopic analysis was performed with a digital paquimeter. The fragments of newly formed tissue were removed from the skin for slides processing and hematoxylin-eosin (HE) and picrosirius red staining techniques, in order to verify the effect of the $10 \%$ "aroeira" cream in different stages of the healing process. Macroscopic analyses demonstrated a decrease in the area of the 10\% "aroeira" cream treated wounds, compared with controls. In addition, the histological study evidenced an improvement in the inflammatory aspects (infiltrate, edema, hemorrhage), in this treated group, as well as the presence of a new epithelium and a greater intensity in collagen deposition. Thus, a favorable effect was observed regarding the use of $10 \%$ "aroeira" cream in the cicatricial process of cutaneous wounds in rats, modulating the inflammatory response of healing and accelerating tissue repair of experimental excisional skin wounds.
\end{abstract}

Keywords Wound healing $\cdot$ aroeira-do-sertão $\cdot$ Collagen $\cdot$ Fibroblasts $\cdot$ Inflammation $\cdot$ Edema

\section{Introduction}

Wounds can be defined as acute or chronic ruptures of any soft parts of the body, with or without damage to its functions, and caused by external and/or internal factors. They can be classified, according to their etiology, complexity, and time of existence (Smaniotto et al. 2010). The healing of a wound is a

Pedro Everson A. de Aquino edil@ufc.br

1 Laboratório de Biofisiologia, Faculdade de Medicina Estácio de Juazeiro do Norte, Juazeiro do Norte, CE, Brazil

2 Departamento de Química Orgânica e Inorgânica, Universidade Federal do Ceará, Fortaleza, CE, Brazil

3 Faculdade de Medicina, Universidade Federal do Ceará, Fortaleza, CE, Brazil dynamic process to restore the structure of the injured tissue. The healing process, divided into three phases, is essential for the local debridement (inflammatory phase), the formation of granulation tissue (angiogenesis), followed by proliferation of fibroblasts, extracellular and collagen matrix formation, reepithelialization, and finally, by the tissue remodeling (Andrade et al. 2011).

There are several diseases that interfere negatively in the tissue repair process, such as diabetes mellitus, systemic sclerosis, anemia, and malnutrition, among others. Additionally, many conditions make this process difficult for resolution, preventing or slowing down the complete restoration of the tissues. By somehow hindering the tissue repair, these diseases contribute to the potential for increased morbidity and mortality (Mendonça and Coutinho-Netto 2009).

The use of medicinal plants for the treatment of pathologies exists since the most remote times, although their acceptance in modern medicine still find resistance (Baharvand-Ahmadi 
et al. 2016). A recent systematic review focusing on the use of medicinal plants for the treatment of skin lesion in humans (clinical trials published from 1997 to 2017), selected ten studies involving 503 patients. Among the medicinal species studied, two of them (Aloe vera and Mimosa tenuiflora) are native from Brazil (Lordani et al. 2018). In addition, evidences (see Shedoeva et al. 2019, for a review) indicate the use of medicinal plants and plant-based products for cutaneous wound. Among the species studied, several stand out including Centella asiatica, Curcuma longa, and Paeonia suffruticosa.

Other studies (Schmidt et al. 2009) on Brazilian plants used in wound healing showed that among twelve plants the extracts from Galinsoga parviflora, Petiveria alliacea, Schinus molle, Waltheria doradinha, and Xanthium cavanillesii were the most active ones. Furthermore, Stryphnodendron adstringens and the oleoresin from Copaifera spp., both species belonging to the Fabaceae family, were also efficacious in wound healing (Ricardo et al. 2018). Interesting data (Veríssimo et al. 2015) from a University Hospital in the city of Maceió, Brazil, interviewing thirty patients bearers of wounds concluded that $70 \%$ of them used medicinal plants to treat varicose ulcers and diabetic foot. The most cited species were Stryphnodendron adstringens, Hyptis pectinata, and Schinus terebinthifolius.

Myracrodruon urundeuva Allemão, Anacardiaceae, popularly known as "aroeira-do-sertão", is a common medicinal species in the state of Ceará, Northeast Brazil and has a wide pharmacological application. In the form of infusion and decoction, it has anti-inflammatory, anti-ulcerous, astringent, anti-allergic, and antidiarrheal activities and is also widely used in the treatment of cutaneous wounds (Viana et al. 1995, 2003).

The need and urgency for new molecules with a healing anti-inflammatory action can provide the market option of a cheaper treatment, increasing the adherence of patients to it by improving their live quality is eminent. For this reason, the present study objective is to evaluate the healing effect of the cream prepared from the decoction of the stem bark of cultivated M. urundeuva (DCCMU), in animals subjected to excisional wounds.

\section{Method}

This study was carried out at the Biophysiology Laboratory of the Faculty of Medicine Estácio of Juazeiro do Norte (Estácio/FMJ), in Juazeiro do Norte, Ceará. The project was approved by the Ethics Committee on Animal Use (CEUA) of the Estácio/ FMJ, under the no. 2017.1-005. The experiments were performed according to the Guide for the Care and Use of Laboratory Animals, 8th. Edition (NIH, USA).

\section{Preparation and Chemical Characterization of the Extract}

The seeds from wild specimens of Myracrodruon urundeuva Allemão, Anacardiaceae, were cultivated in the horticulture sector of the Federal University of Ceará (UFC, Fortaleza, Brazil), in February 2012, and the exsiccatae are deposited at the UFC Prisco Bezerra Herbarium, under the number 48,904 . The stem bark of a cultivated specimen of the $(E)-\beta$ ocimene chemotype was obtained from a 7-year-old plant.

Dried and powdered stem bark was submitted to decoction for obtaining the extract called MUCCCD. The decoction was characterized by ultra-efficiency liquid chromatography coupled to mass spectrometry (UPLC-ESI-TOF-EM), according to the methodology described by Aquino (2017). The decoction of the stem bark of the cultivated "aroeira" (MUCCCD) was subjected to a study of dereplication by HPLC-ESI-QTOF-EM. The identification of the compounds was performed by comparing the data obtained in both negative and positive modes, with data from the literature (Table 1). The compounds were identified and classified into seven groups: non-protein amino acids, carboxylic acids, catechins, chlorogenic and cinnamic acids derivatives, hydrolysable tannins, condensed tannins, and dimeric chalcones (Aquino 2017).

\section{Preparation of the Cream}

The cream of "aroeira" was developed at the Center for Studies of Pharmaceuticals and Cosmetics, Federal University of Ceará. It was carried out with cold neutralization and under agitation in an aqueous solution containing $1 \%$ of carboxyvinyl polymer, $5 \%$ glycerin, and $1 \%$ polypropyleneglycol. Methylparaben (0.15\%) and propylparaben $(0.05 \%)$ were added as preservatives and aminometilpropanol (q.s. $100 \mathrm{~g}$ ) at pH 6.5 as a neutralizing agent. This cream was used as a control (base cream) and in the preparation of the $10 \%$ "aroeira" cream.

\section{Animals}

Male Wistar rats (200-250 g), from the Animal House of the Faculty of Medicine of Juazeiro do Norte (Estácio/FMJ), were shelted in cages (one animal per cage) in an air-conditioned environment, at the temperature of $24 \pm 2{ }^{\circ} \mathrm{C}$, under light/dark cycle conditions (12 h/12 h), with free access to a standard ration (Purina Chow) and drinking water. The animals were treated in accordance with current legislation and the ethical principles established by the Brazilian National Council for the Control of Animal Experimentation (CONCEA).

In order to perform all surgical procedures described as follow, the animals were anesthetized intraperitoneally (i.p.) with $10 \%$ ketamine hydrochloride, associated with $2 \%$ 


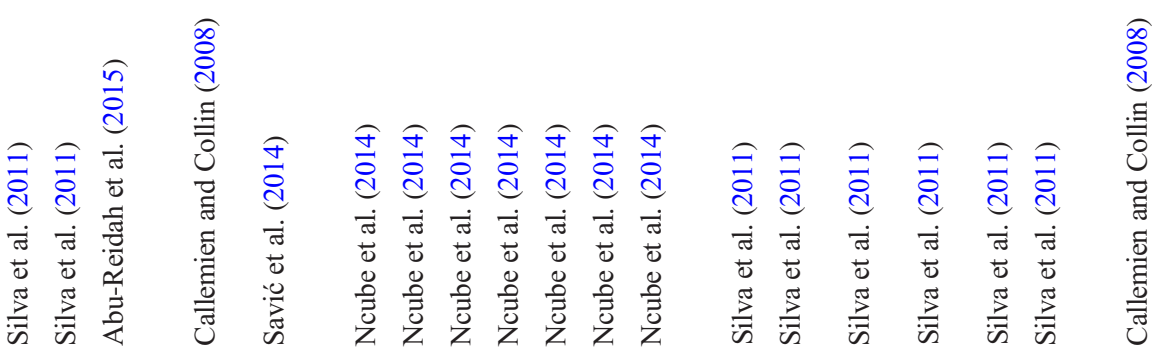

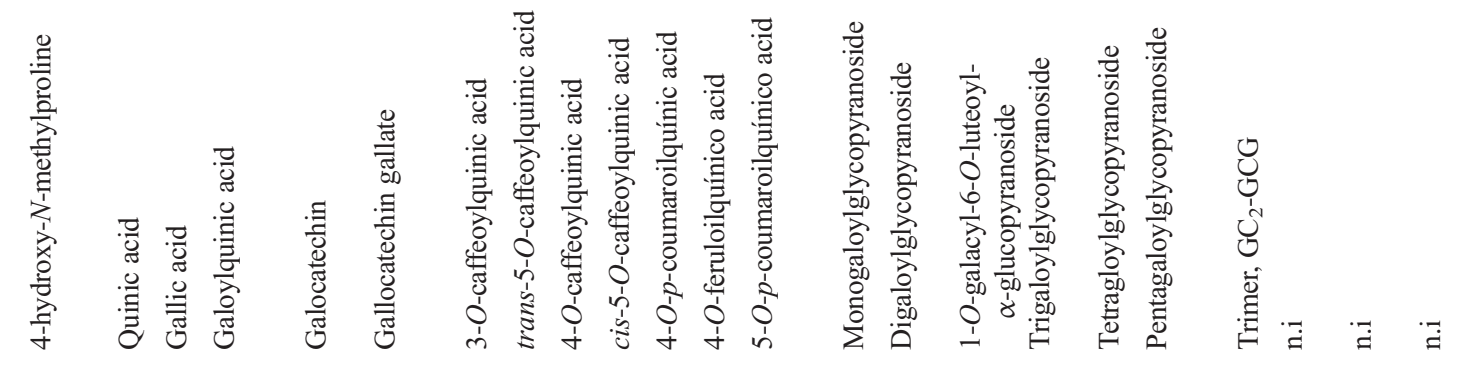

竘

卢

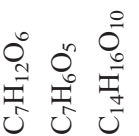

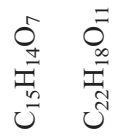

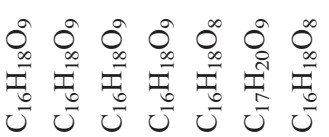

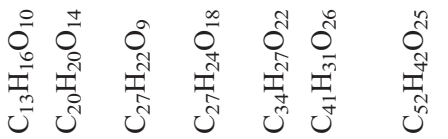

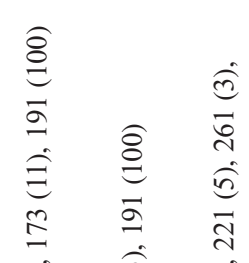

$\approx$ ले लि

过

\&ᄋㅇㅇ

i iे

$\stackrel{\varrho}{\ominus}$

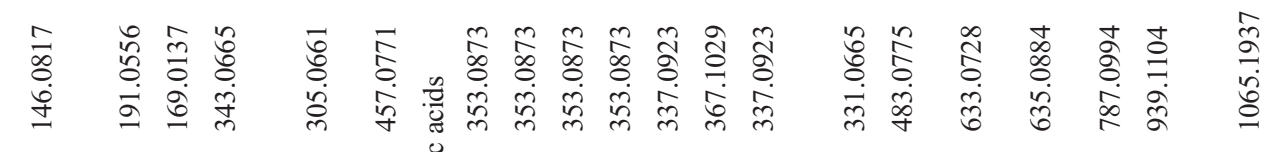

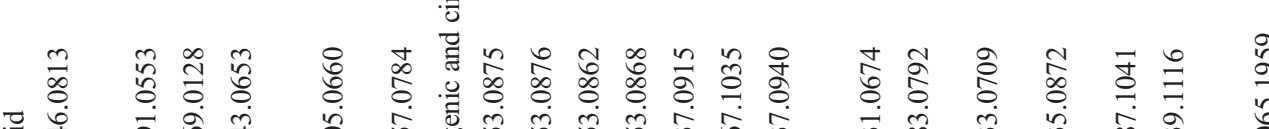

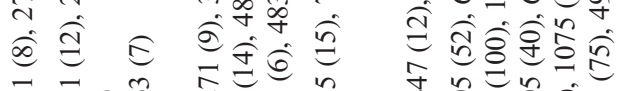

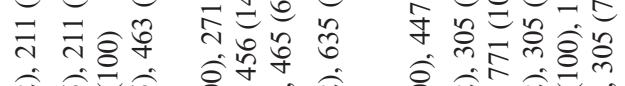

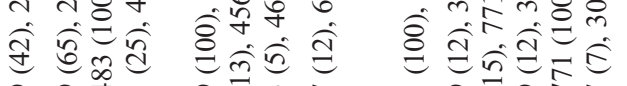

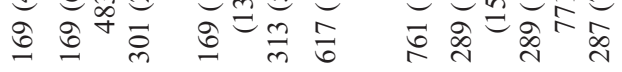




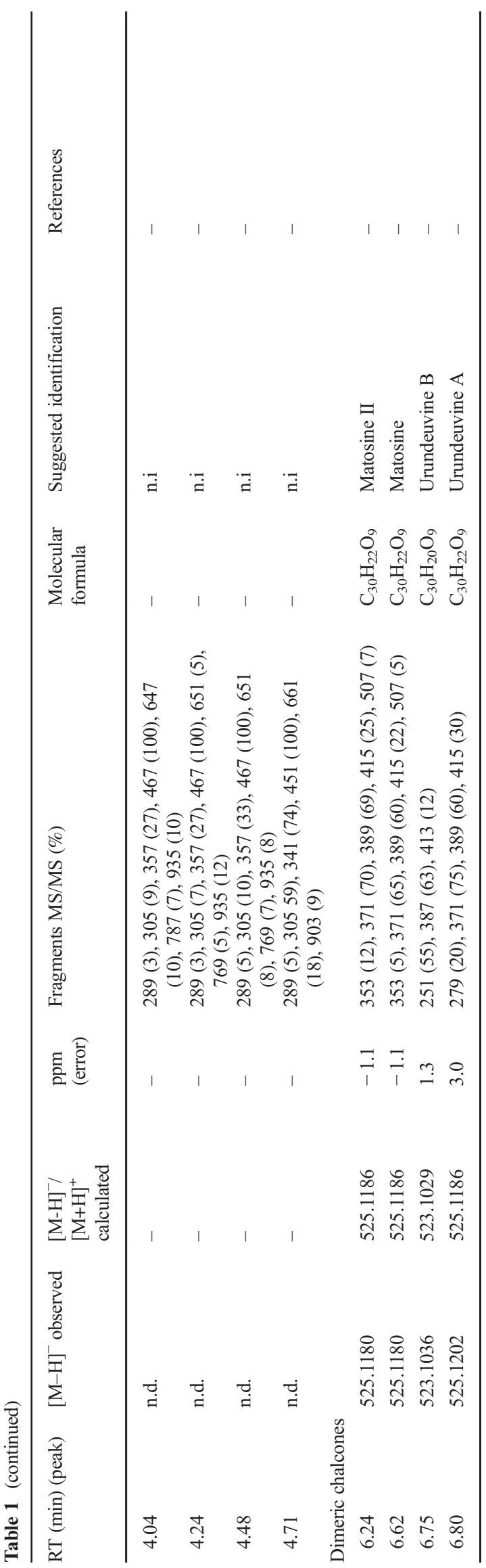

xylazine hydrochloride at doses of $100 \mathrm{mg} / \mathrm{kg}$ and $10 \mathrm{mg} / \mathrm{kg}$, respectively (Hall et al. 1991).

After surgery, the animals received an intraperitoneal single dose of dipirone (Medley S/A, Campinas, SP, Brazil), $50 \mathrm{mg} / \mathrm{kg}$ body weight, diluted in saline for postoperative analgesia. At the end of the surgical procedure, the animals received subcutaneously (s.c.) $1 \mathrm{ml}$ saline for fluid replacement and were maintained in a heated environment until complete recovery of anesthesia. After evaluation performed for 12 days past the surgical induction of the cutaneous lesion, the animals were anesthetized and euthanized by cervical displacement.

\section{Healing Model by Second Intention (Excisional Wounds)}

Two $8 \mathrm{~mm}$ diameter circular excisional wounds were induced to the dorsal surface of the animals, using a surgical punch for skin biopsy (Canesso 2014). At the end of the surgical procedures, the animals received subcutaneously (s.c.) $1 \mathrm{ml}$ sterile saline solution for fluid replacement and were kept in a heated environment until the complete recovery from anesthesia.

\section{Standardization of Experimental Groups}

To all approaches described in this work, ten animals/group were used. They were divided into the following groups: sham group (animals undergoing surgical procedures of skin lesion induction, without any treatment); control group (animals submitted to surgical procedures of cutaneous lesion induction, followed by treatment with base cream); $10 \%$ "aroeira" cream group, $10 \%$ M. urundeuva (animals undergoing surgical procedures for the induction of cutaneous lesion, followed by treatment with $10 \%$ "aroeira" cream).

\section{Macroscopic Analysis of Excisional Wounds}

The area of excisional wounds was estimated on days $1,3,5$, 7,9 , and 11 , after surgery ( $n=1$ /group/day), by measuring the cranial-caudal and latero-lateral diameters, with the aid of a digital paquimeter, and the calculation of the area by the equation: $a=\pi$.R.r, where "a" represents the area, " $\mathrm{R}$ " the greater radius, and " $\mathrm{r}$ " the minor radius of the wound (Prata et al. 1998).

\section{Collection of Tissue Samples for Histological Analysis}

Approximately $2 \mathrm{~mm}$ cylindrical tissue fragments were withdrawn from the neoformed tissue over the surgery region $(n=$ 5/group/day) after skin removal, on days 2, 7, and 12 , for the macroscopic study, as described previously. This procedure was performed with the use of an $8 \mathrm{~mm}$ diameter punch. 
After tissue collection, the animals were submitted to euthanasia by cervical displacement.

\section{Histological Analysis}

After removal, the tissues were fixed in a buffered solution of formaldehyde $10 \%(\mathrm{~V} / \mathrm{V})(\mathrm{pH} 7.4)$ for $24 \mathrm{~h}$ and subsequently processed in the usual histological pattern. With the aid of a microtome, $5 \mu \mathrm{m}$ thick sections were arranged in microscopy slides and submitted to hematoxylin-eosin (HE) staining techniques and picrosirius red. From the histological slides, photomicrographs were obtained by an optical microscope, coupled to a high resolution digital camera. The captured images were saved in JPEG format and analyzed by the ImageJ 1.43 software (U.S. National Institutes of Health) (Noursadeghi et al. 2008).

\section{Statistical Analysis of Data}

The analyses were performed with the Graph Pad Prism software, version 5.0. The results were expressed as mean \pm SEM or median, according to the parameter evaluated. The data were analyzed by ANOVA followed by Tukey's as the post hoc test, for multiple comparisons. $p$ values $<0.05$ represented significant statistical differences between the data, under a confidence interval of $95 \%$.

\section{Results and Discussion}

When analyzing from the macroscopic point of view, the epidermis of all groups, the presence of crust was observed on the 7th postoperative day and the absence of reepithelialization. While, on the 9th day, the evidence of partial reepithelialization associated with the persistence of crusts was possible to detect. On the 11th day, the occurrence of total reepithelialization was noted (Fig. 1).

The mean area of the lesions was determined with the aim of investigating the effect of topical treatments on excisional wound contraction. The measurements were performed on days $1,3,5,7,9$, and 11, after the induction of the wound (Fig. 3). There was a greater contraction of the wounds treated with $10 \%$ "aroeira" cream $(p<0.05)$, when compared with the untreated groups (Sham) and treated with base cream (vehicle, V).

The histological analysis reveals an improvement in the inflammatory aspects (infiltration, edema, hemorrhage) for the group treated with $10 \%$ "aroeira" cream, as well as the presence of a new epithelium, only on the 7th and 12th days of treatment.

Collagen was quantitatively evaluated on the 7 th and 12th days after treatment of excisional wounds. Photomicrographs of histological slides stained by picrosirius red were captured to represent the process of collagen in all experimental groups (Fig. 4). On the seventh day, the wounds of the sham group had lower collagen deposition, compared with other experimental groups, but no difference was found in relation to the vehicle. The group treated with $10 \%$ "aroeira" cream showed the highest intensity in collagen deposition, demonstrating a significant difference. In the polarized images, the highest presence of collagen type I can be observed (red color) in the group treated with the $10 \%$ "aroeira" cream (Fig. 5).

The treatment of wounds has challenged health professionals especially in chronic disease patients. Brazil with is enormous biodiversity offers several options for the pharmaceutical industry by focusing on medicinal plants and their bioactive components. Several medicinal species point out as promising as Stryphnodendron adstringens, Carapa
Fig. 1 Macroscopic analyses of excisional wounds on different days of induction. The images represent excisional wounds evaluated in the 7th, 9th, and 11th days after surgery. The topical treatment was performed with $10 \%$ "aroeira" cream. The animals belonging to the Sham group were subjected to the surgical procedure but did not receive any treatment

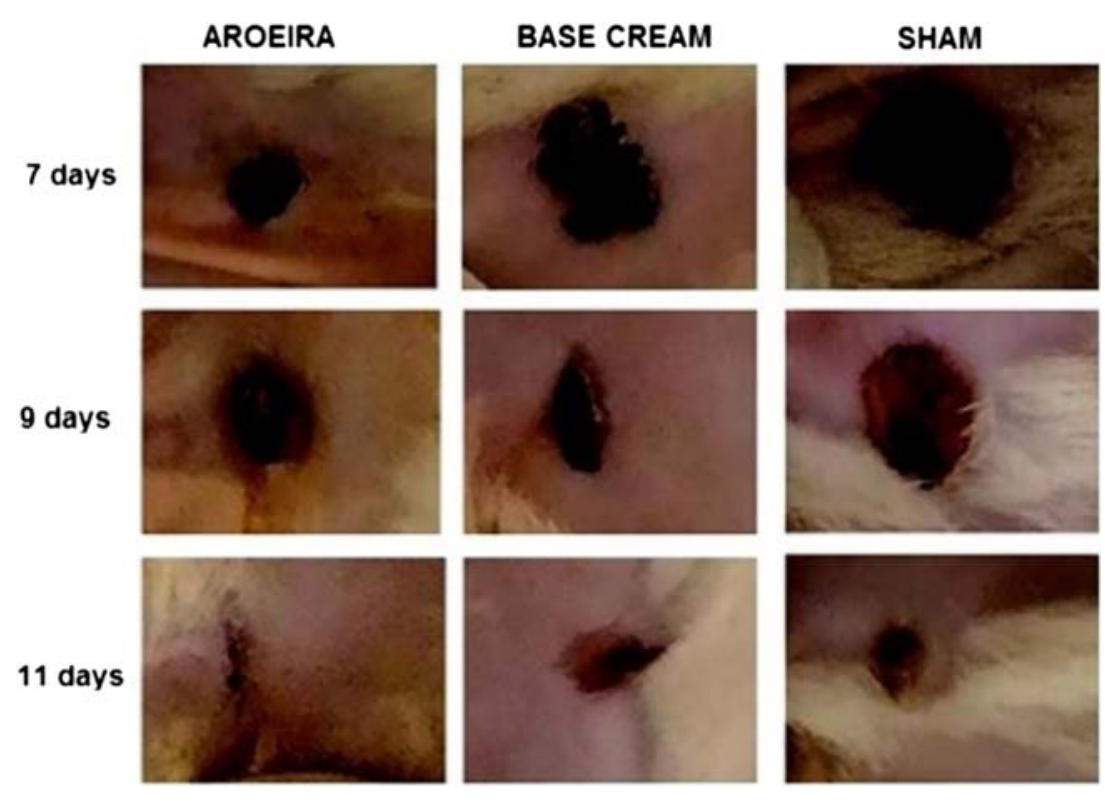


guianensis, Capaifera langsdorffii, and Schinus terebenthyfolius, which also belongs to the same family as M. urundeuva, among others (Veríssimo et al. 2015; Souza et al. 2017; Gushiken et al. 2017; Ricardo et al. 2018).

There are currently numerous options for topical treatment of wounds but despite this diversity, there are scarce evidences relative to the efficacy in promoting healing. Thus, the present study investigated the cicatrizing effect of Myracrodruon urundeuva and the use in Northeast Brazil for its anti-inflammatory, analgesic, and also cicatricial actions (Viana et al. 2003). M. urundeuva is listed by the Brazilian Institute of Environment and Renewable Natural Resources (IBAMA) as an endangered species and thus the stem bark used in the present study came from a cultivated specimen. Although "aroeira" is widely disseminated as a cicatricial agent, few scientifically methodological studies have been produced to confirm its specific efficacy in the treatment of wounds, with results empirically known (Viana et al. 1995).

From macroscopic examination, on the third postoperative day, the wounds of animals belonging to the group treated with "aroeira" cream were hyperemic and with edematous edges. At the seventh postoperative day, the wounds were covered by a thin crust, a process which was also observed in the works of Santos et al. (2006), Martins et al. (2006), and Branco-Neto et al. (2006). These authors described that skin removal induces the development of continuity solution, filled by fibrin, clot, exudate inflammation, forming the crust that covers the wound.

As demonstrated, there was a decrease in the wound area treated with "aroeira" cream, in relation to the controls and contrasting with the data found by Branco-Neto et al. (2006), where the hydroalcoholic extract of another species of "aroeira" (Schinus terebinthifolius) delayed the reepithelialization of the skin wounds of rats, presenting an average area larger than that in the control group.

Tissue repair is a dynamic state that comprises different processes, including inflammation, cell proliferation, and synthesis of elements that constitute the extracellular matrix, such as collagen, elastin, and reticular fibers. Viana et al. (2003) showed an anti-inflammatory effect of "aroeira", in the model of carrageenan-induced paw edema. In this study, the histological analysis demonstrated a decrease in the inflammatory process and formation of a new epithelium, in addition to increased deposition of collagen in the skin, favoring the tissue repair, in rats. The same was observed by Estevão et al. (2017), with the cream of Schinus terebinthifolius, also belonging to the Anacardiaceae family.

According to Isaac et al. (2010), there is in the wound a higher proportion of type III collagen in relation to type I, thus myofibroblasts bind collagen fibers of type III, promoting wound contraction. So, the higher the number of type III collagen fibers present, the greater the contraction of the wound. These type III collagen fibers are present, from days 3 to 5 after the injury, being progressively replaced by type I collagen fibers. At the end of 2 weeks, type I collagen fibers are prevalent.

Our study therefore showed that the group treated with the cream of "aroeira" presented a higher percentage of type I collagen fibers, from the 7th day of treatment, as shown in Fig. 2, thus promoting a process of greater tissue repair.

The chromatography analysis showed the presence of secondary metabolites, among them, catechins, derivatives of the
Fig. 2 Representative photomicrographs of histological slides stained by HE, on 2, 7, and 12 days of treatment. An extensive inflammatory infiltrate can be evidenced on the 2nd day of treatment in all groups and the presence of crust and hemorrhage. The figures of the 7th and 12th days present thickness of the new epithelium in the group treated with $10 \%$ "aroeira" cream, as well as a drastically decreased inflammatory process and extracellular matrix deposition
2 days

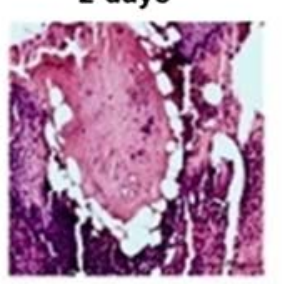

CONTROL

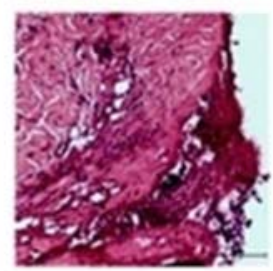

$10 \%$ AROEIRA

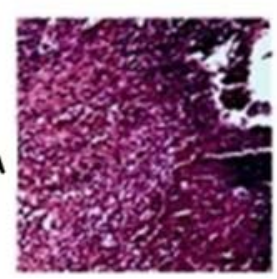

7 days
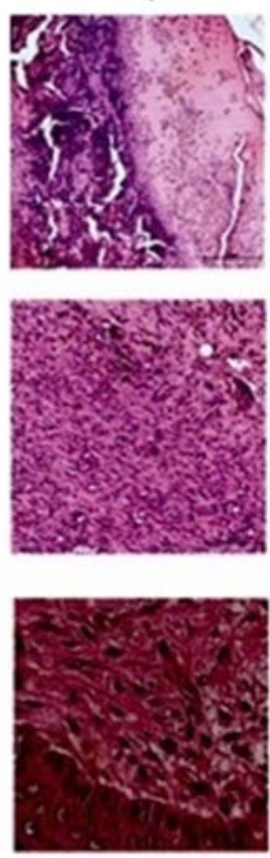

12 days
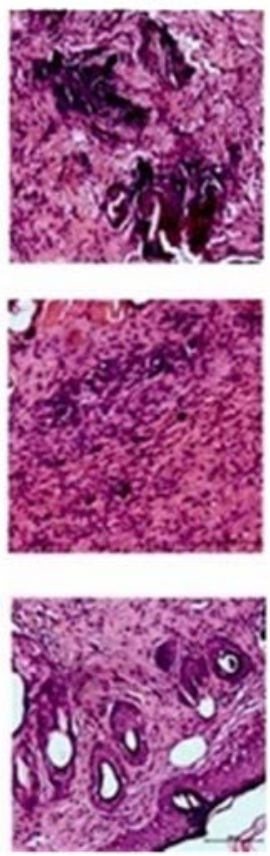
cinnamic acid, hydrolysable and condensed tannins, in addition to dimeric chalcones. Chalcones belong to the flavonoid class, which in addition to an antioxidant activity has an antiinflammatory effect (Zuanazzi 2010). Sousa et al. (2007) reported the anti-inflammatory and anti-ulcerogenic activities of a fraction enriched with tannin, from the trunk bark of "aroeira". The tannins helped in the healing processes of wounds, burns and inflammations, forming a protective layer (tannin-protein complex) on epithelial tissue lesions and leading to the curative process occurring naturally (Monteiro et al. 2005).

In addition to these compounds, it is important emphasize the presence of the non-proteic amino acid, the trans-4-hydroxy- $N$-methylproline, in the cultivated and non-cultivated specimens of M. urundeuva. The quimic acid can be found in several species, such as Uncaria tomentosa, Aster scaber, and Saussurea triangulata. Another evidence (Akesson et al. 2005) showed that the quinic acid inhibits the activity of the NF-kB nuclear transcription factor, intimately involved with Inflammatory processes (Tak and Firestein 2001; Lawrence 2009). Recently (Aquino 2017), the anti-inflammatory effects of 4-hydroxy- $N$-methylproline were found, for the first time, in the species Syderoxylon obtusifolium, associated with the inhibitory actions of pro-inflammatory cytokines, TNF-alpha, and inflammatory enzymes. Therefore, these two compounds, quinic acid and trans-4-hydroxy- $N$-methylproline, also present in M. urundeuva, can certainly contribute to the healing actions demonstrated in the present work.

The presence of bacterial infection is able to prolong in particular the inflammatory phase, due to the production
Fig. 3 Evolution of the wound areas during the healing process. The animals were submitted to surgery for the induction of the wound and distributed among the experimental groups. The topical treatment was carried out with a vehicle and cream containing the $10 \%$ "aroeira" cream. The animals belonging to the Sham group were subjected to the surgery procedure but did not receive any treatment. The wound area was planimetrically

determined on days 1, 3, 5, 7, 9, and 11 after surgery. The results are expressed as the mean \pm SEM for wounds area $* p<0.05$. ANOVA followed by Tukey's post hoc test
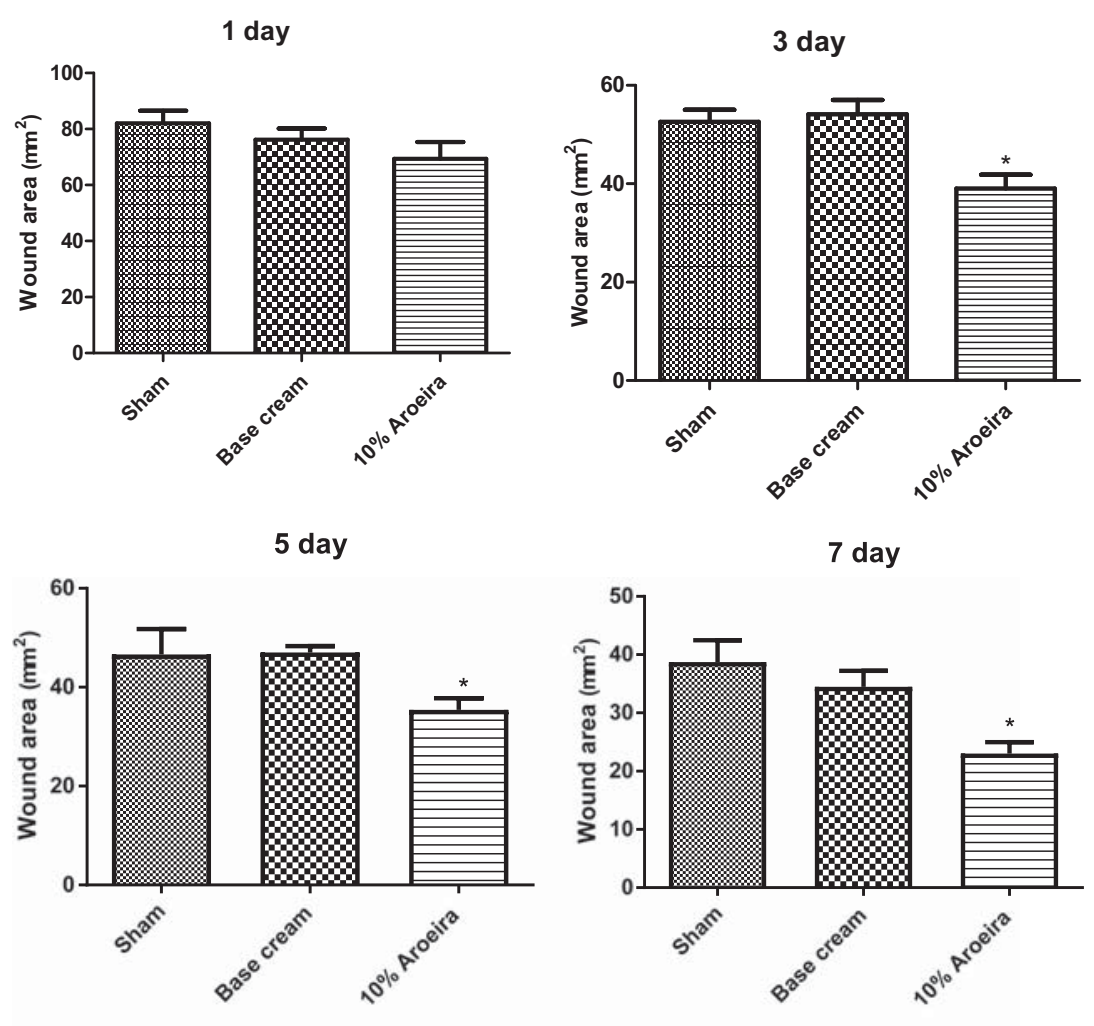

9 day
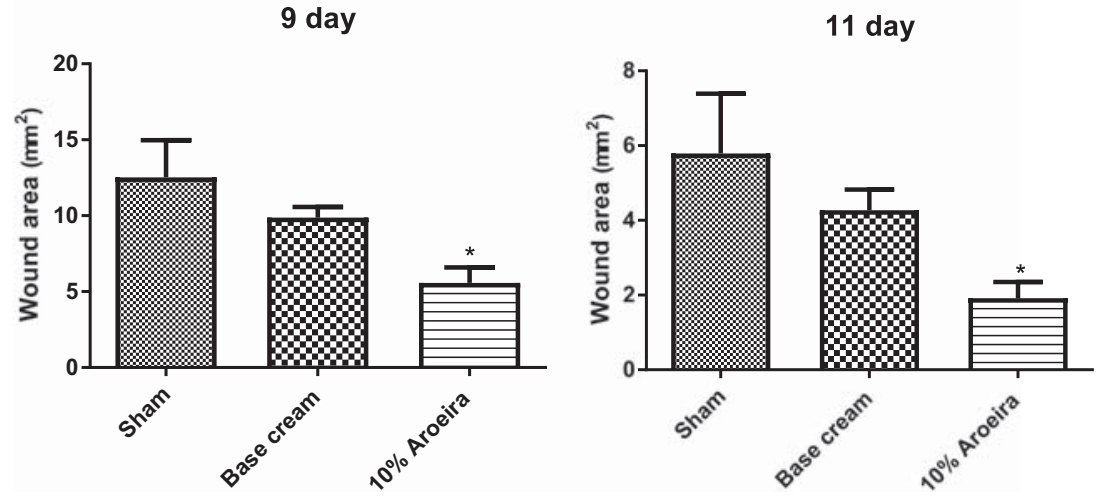
Fig. 4 Photomicrographs from picrosirius red staining (polarized and non-polarized) of tissue repair in rats, demonstrating collagen formation
Aroeira 7 days

Base Cream

7 days

Base Cream

12 days

Sham 7 days

Sham 12 days
Aroeira 12 days

Non-polarized

Polarized

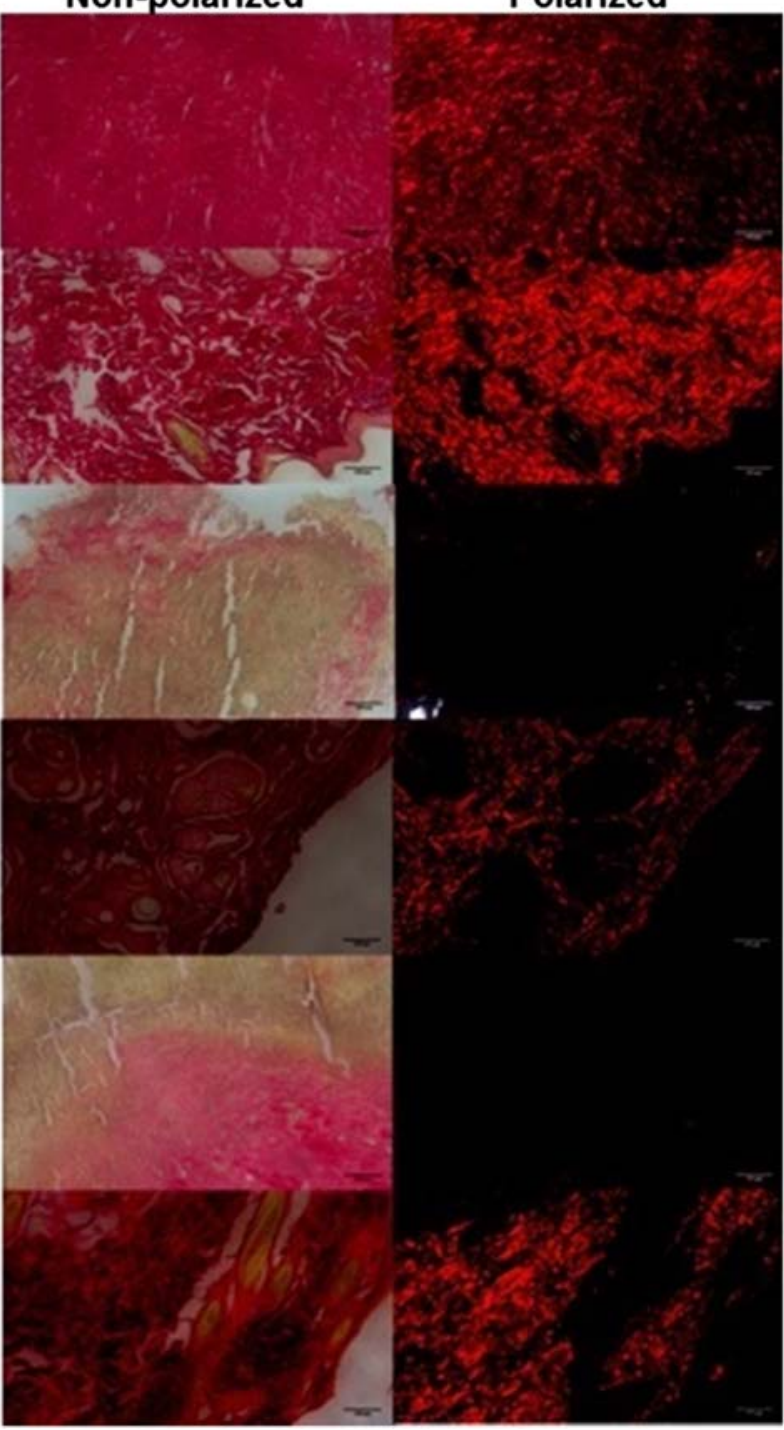

12 day

7 day

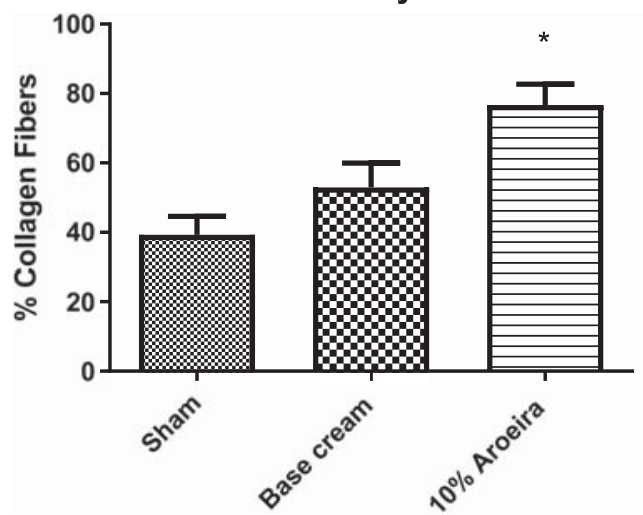

Fig. 5 Effect of topical treatment with 10\% "aroeira" fraction on collagen deposition. Excisional wounds were collected on the 7th and 12th days after treatment, for the preparation of histological slides, subsequently stained by the method of picrosírius red staining. The quantification of the collagen was performed, in images $(372 \times 272$ pixels $)$ of each wound,

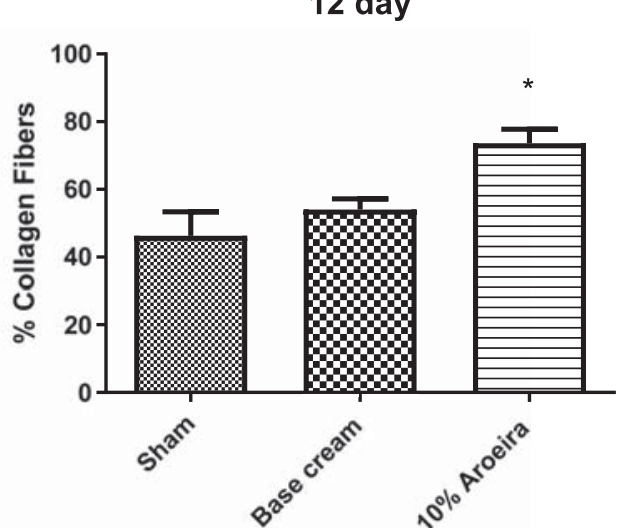

through the plugin "Color deconvolution" of the ImageJ Software. The results were expressed as the mean \pm SEM for the percentage of the total number of collagen fibers. $* p<0.05$. ANOVA, followed by Tukey as the post hoc test 
increase of pro-inflammatory principles (Guo and DiPietro 2010). Excisional wounds have greater risk of infection by providing an entrance door, especially to bacteria. If the tissue infects, the wound takes more time to heal and a strong exudate is formed as consequence of the infection (Schmidt et al. 2009).

Jandú et al. (2013), Gomes et al. (2013), and Sá et al. (2009) demonstrated the antibacterial activity of "aroeira" against gram-positive and gram-negative bacteria, mainly by the composition of their secondary metabolites that mainly involve tannins, flavonoids, and alkaloids. Others (Albuquerque et al. 2011) demonstrated that chalcones from M. urundeuva stem barks presented anti-inflammatory and antioxidant effects and drastically inhibited myeloperoxidase (inflammation marker) activity pointing them as potential candidates for the treatment of inflammatory conditions. In addition, an important neuroprotective property of a standardized extract (rich in tannins and chalcones) from M. urundeuva that was shown to be effective on a Parkinson's disease model in rats (Calou et al. 2014). All these findings strengthen our work on the use of M. urundeuva for several purpose were inflammatory processes are present.

\section{Conclusion}

After analyzing the results obtained, the topical use of the cream of Myracrodruon urundeuva proved to be efficient in the process of wound repair in male Wistar rats. Since the treatment of chronic cutaneous wounds results in high costs and risks of complications that may delay the resolution of the healing process, this study may be used as a parameter for future translational research related to this species.

Authors' Contributions MCT, wrote the first draft of the manuscript; MJPL, DLSJ, AESR, BSP, contributed to the execution of the experimental tests and animal's care; PEAA, helped with the first draft of the manuscript and its submission to BJP; NCA and ERS, responsible for the preparation and chemical characterization of the extract from Myracrodruion urundeuva stem bark; LKAML, responsible for the preparation of the M. urundeuva aroeira cream; GSBV, coordinated the Project and was responsible for its final written version. All authors read and approved the final manuscript submission.

\section{Compliance With Ethical Standards}

Protection of Animal Subjects The authors declare that the procedures followed were in accordance with the regulations of the relevant clinical research ethics and with those of the Code of Ethics of the World Medical Association (Declaration of Helsinki).

Confidentiality of Data The authors declare that they have followed the protocols of their work center on the publication of patient data.

Conflict of Interest The authors declare that they have no conflicts of interest.
Open Access This article is licensed under a Creative Commons Attribution 4.0 International License, which permits use, sharing, adaptation, distribution and reproduction in any medium or format, as long as you give appropriate credit to the original author(s) and the source, provide a link to the Creative Commons licence, and indicate if changes were made. The images or other third party material in this article are included in the article's Creative Commons licence, unless indicated otherwise in a credit line to the material. If material is not included in the article's Creative Commons licence and your intended use is not permitted by statutory regulation or exceeds the permitted use, you will need to obtain permission directly from the copyright holder. To view a copy of this licence, visit http://creativecommons.org/licenses/by/4.0/.

\section{References}

Abu-Reidah IM, Ali-Shtayeh MS, Jamous RM, Araez-Roman D, SeguraCarretero A (2015) HPLC-DAD-ESI-MS/MS screening of bioactive components from Rhus coriaria L. (Sumac) fruits. Food Chem 166:179-191

Akesson C, Lindgren H, Pero RW, Leanderson T, Ivars F (2005) Quinic acid is a biologically active component of the Uncaria tomentosa extract C-Med 100. Int Immunopharmacol 5:219-229

Albuquerque RJM, Leal LKAM, Bandeira MA, Viana GSB, Rodrigues LV (2011) Chalcones from Myracrodruon urundeuva are efficacious in guinea pig ovalbunin-induced allergic conjunctivities. Rev Bras Farmacogn 21:953-962

Andrade TA, Iyer A, Das PK, Foss NT, Garcia SB, Coutinho-Netto J, Jordão-Jr AA, Frade A (2011) The inflammatory stimulus of a natural latex biomembrane improves healing in mice. Braz J Med Biol Res 44:1036-1047

Aquino NC (2017) Aspectos químicos do estudo químicofarmacológico-agronômico de aroeira-do-sertão (Myracrodruon urundeuva Fr. All), silvestres e cultivadas. $451 \mathrm{f}$. Tese (Doutorado em Química), Universidade Federal do Ceará, Fortaleza

Baharvand-Ahmadi B, Bahmani M, Tajeddini P, Naghdi N, RafieianKopaei M (2016) An ethno-medicinal study of medicinal plants used for the treatment of diabetes. J Nephropathol 5:44-50

Branco-Neto MLC, Ribas-Filho JM, Malafaia O, Oliveira-Filho MA, Czeczko NG, Aoki S, Cunha R, Fonseca VR, Teixeira HM, Aguiar LRF (2006) Avaliação do extrato hidroalcoólico de aroeira (Schinus terebinthifolius Raddi) no processo de cicatrização de feridas de pele em ratos. Acta Cir Bras 21:17-21

Callemien D, Collin S (2008) Use of RP-HPLC-ESI(-)-MS/MS to differentiate various proanthocyanidin isomers in lager beer extracts. $\mathrm{J}$ Am Soc Brewing Chem 66:109-115

Calou I, Bandeira MA, Aguiar-Galvão W, Cerqueira G, Siqueira R, Neves KR, Brito GA, Viana G (2014) Neuroprotective properties of a standardized extract from Myracrodruon urundeuva Fr. All. (aroeira-do-sertão), as evaluated by a Parkinson's disease model in rats. Parkinson's Dis. https://doi.org/10.1155/2014/519615

Canesso MCC (2014) Avaliação da cicatrização de feridas cutâneas em animais isentos de microbiota comensal. 102 p. Dissertação, Departamento de Fisiologia e Biofísica, Universidade Federal de Minas Gerais, Belo Horizonte, Brasil

Estevão LRM, Simões RS, Cassini-Vieira P, Canesso MCC, Barcelos LSB, Rachid MA, Câmara CAG, Evêncio-Neto J (2017) Schinus terebinthifolius Raddi (aroeira) leaves oil attenuates inflammatory responses in cutaneous wound healing in mice. Acta Cir Bras 32: 726-735

Gomes VTL, Chaves TP, Alencar LCB, Dantas IV, Medeiros ACD, Felismino DC (2013) Antimicrobial activity of natural products 
from Myracrodruon urundeuva Allemão (aroeira-do-sertão). Rev Cubana Pl Med 18:529-533

Guo S, Dipietro LA (2010) Factors affecting wound healing. J Dental Res 83:219-222

Gushiken LFS, Hussni CA, Bastos JK, Rozza AI, Padovani CR, Takashira RK, Pellizzon CH (2017) Hydroalcoholic extract from Copaifera landsdorffii has skin wound healing activity in rats. Int J Complem Alt Med. https://doi.org/10.15406/ijcam.2017.06.00178

Hall LW, Clark KW, Trim CM (1991) Anaesthesia of birds, laboratory animals and wild animals. In: Hall LW, Clark KW, Trim CM (eds) Veterinary Anaesthesia. 9a ed. W. B. Saunders Company, Philadelphia, pp 339-351

Isaac C, Ladeira PRS, Rego FMP, Aldunate JCB, Ferreira MC (2010) Processo de cura das feridas: cicatrização fisiológica. Rev Med 89: $125-131$

Jandú JJB, Silva LCN, Pereira APC, Souza RM, Silva-Júnior CA, Figueiredo RCBQ, Araújo JM, Correia MTS, Silva MV (2013) Myracrodruon urundeuva bark: an antimicrobial, anti-oxidant and non-cytotoxic agent. J Med Pl Res 7:413-418

Lawrence T (2009) The nuclear factor NF-kB pathway in inflammation. Cold Spring Harb Perspect Biol 1:a001651

Lordani TVA, de Lara CE, Ferreira FBP, Monich M, de Souza T, da Silva CM, Lordani CRF, Bueno FG, Teixeira JJV, Lonardoni VC (2018) Therapeutic effects of medicinal plants on cutaneous wound healing in humans: a systematic review. Mediat Inflam. https://doi.org/10. $1155 / 2018 / 7354250$

Martins NLP, Malafaia O, Ribas-Filho JM, Heibel M, Baldez RN, Vasconcelos PR.L, Moreira H, Mazza M, Nassif PAN, Wallbach TZ (2006) Análise comparativa da cicatrização da pele, com o uso intraperitoneal de extrato aquoso de Orbignya phalerata (babaçu). Estudo controlado em ratos. Acta Cir Bras 21:66-75

Mendonça RJ, Coutinho-Netto J (2009) Aspectos celulares da cicatrização. An Bras Dermatol 84:257-256

Monteiro JM, Albuquerque UP, Araújo EL, Amorim ELC (2005) Taninos: uma abordagem da química à ecologia. Quim Nova 28: 892-896

Ncube EN, Mhlongo MI, Piater LA, Steenkamp PA, Dubery IA, Madala NE (2014) Analyses of chlorogenic acids and related cinnamic acid derivates from Nicotiana tabacum tissues with the aid of ULPCQTOF-MS/MS based on the in-source collision-induced dissociation method. Chem Central J 8:66-75

Noursadeghi M, Tsang J, Haustein T, Miller RF, Chain BM, Katz DR (2008) Quantitative imaging assay for NF-kB nuclear translocation in primary human macrophages. J Immunol Meth 329:194-200

Prata MB, Haddad CM, Goldenberg S, Simöes MJ, Moura LAR, Trabulsi LR (1998) Usotópico do açúcar em ferida cutânea. Estudo experimental em ratos. Acta Cir Bras 3:43-48

Ricardo LM, Dias BM, Mügge FLB, Leite VV, Brandão MGL (2018) Evidence of traditionality of Brazilian medicinal plants: the case studies of Stryphnodendron adstringens (Mart.) Coville (barbatimão) barks and Copaifera spp. (copaiba) oleoresin in wound healing. J Ethnopharmacol 219:319-336
Sá RA, Gomes FS, Napoleão TH, Santos NDL, Melo CML, Gusmão NB, Coelho LCBB, Paiva PMG, Bieber LW (2009) Antibacterial and antifungal activities of Myracrodruon urundeuva heartwood. Wood Sci Technol 43:85-95

Santos MFS, Czeczko NG, Nassif PAN, Ribas-Filho JM, Alencar BLF, Malafaia O, Ribas CAPM, Trautwein VM, Henriques GS, Maia JMA, Bittencourt RCA (2006) Avaliação do uso do extrato bruto de Jatropha gossypiifolia L. na cicatrização de feridas cutâneas em ratos. Acta Cir Bras 21:2-7

Savić IM, Nikolić VD, Savić IM, Nikolić LB, Jović MD, Jović MD (2014) The qualitative analysis of the green tea extract using ESIMS method. Adv Technol 3:30-37

Schmidt C, Fronza M, Goettert M, Geller F, Luik S, Flores EM, Bittencourt CF (2009) Biological studies on Brazilian plants used in wound healing. J Ethnopharmacol 122:523-532

Shedoeva AL, Leavesley D, Upton Z, Fan C (2019) Wound healing and the use of medicinal plants. Evid Based Complement Altern Med. https://doi.org/10.1155/2019/26844108

Silva VC, Napolitano A, Eletto D, Rodrigues CM, Pizza C, Vilegas W (2011) Characterization of gallotannins from Astronium species by flow injection analysis- electrospray ionization-ion trap-tandem mass spectrometry and matrix-assisted laser desorption/ionization time-of-flight mass spectrometry. Eur J Mass Spectrom 17:365-375

Smaniotto PHS, Galli R, Carvalho VF, Ferreira MC (2010) Tratamento clínico das feridas - curativos. Rev Med 89:137-141

Sousa SM, Aquino LC, Milach AC, Bandeira MA, Nobre ME, Viana GS (2007) Anti-inflammatory and anti-ulcer properties of tannins from Myracrodruon urundeuva Allemão (Anacardiaceae) in rodents. Phytother Res 21:220-225

Souza BAA, Braga LA, Lopes LRO, Ribeiro-Júnior RFG, Nascimento LNS, Cavalcante LCC, Monteiro AM, Couteiro RP, Yasojima EY, Hamoy M (2017) Effects of andirioba oil (Carapa guianensis) on wound healing in alloxan-diabetic rats. Int Arch Med. https://doi. org $/ 10.3823 / 2533$

Tak PP, Firestein GS (2001) NF-kB: a key role in inflammatory diseases. J Clin Invest 107:7-11

Veríssimo RCSS, Bernardo THL, Araújo MGS, Ataíde MM, Viana MDM, Alvino V, dos Santos RFEP, Alexandre-Moreira MS, Bastos MLA, Araújo-Júnior JX (2015) Medicinal plants used in the wounds treatment. J Chem Pharm Res 7:64-69

Viana GSB, Matos FJ, Bandeira MAM, Rao VSN (1995) Aroeira-dosertão (Myracrodruon urundeuva Allemão): estudo botânico, farmacognóstico, químico e farmacológico. 2.ed. EUFC, 160p

Viana GSB, Bandeira MAM, Matos FJA (2003) Analgesic and antiinflammatory effects of chalcones isolated from Myracrodruon urundeuva. Phytomedicine 10:189-195

Zuanazzi JAS (2010) Flavonóides. In: Simões CMO, Schenkel EP, Grosmann G, Melo JCP, Mentz LA, Petrovick PR (Eds), Farmacognosia: da planta ao medicamento. $6^{\mathrm{a}}$ ed. Porto Alegre: Editora da UFRGS: Florianópolis: Editora da UFSC, 1104 p 